\title{
Accounting and information systems in Irish family SME: professionalisation effects
}

\author{
Martin Quinn $^{\mathrm{a}}$, Peter Cleary ${ }^{\mathrm{b}}$, Catherine Batt ${ }^{1, \mathrm{c}}$, Pall Rikhardsson ${ }^{\mathrm{c}}$ \\ ${ }^{a}$ Queen's Management School, Queen's University, United Kingdom \\ ${ }^{b}$ Cork University Business School, University College Cork, Ireland \\ ${ }^{c}$ Copenhagen Business School, Copenhagen, Denmark.
}

\begin{abstract}
Research Question: Does the use of IS in family businesses differ significantly from nonfamily businesses? Does professionalisation of accountants positively impact the use of IS, and is there a difference between family and non-family businesses?

Motivation: Research indicates family businesses have more limited implementation and use of information systems (IS) coupled with less accounting and control. As accounting is a primary user of IS, this paper explores if professionalisation of accounting may explain such reported differences in IS use.
\end{abstract}

Idea: This study tests two hypotheses around IS use and professionalisation of accounting. Using a more refined measure of professionalisation of accounting than previous.

Data: Data was collected from a survey of CFOs in a country with a strong family business tradition and strong professional accounting bodies. A response rate of $30 \%$ was achieved.

Tools: A Mann-Witney test coupled with binary and multi-nominal regressions were used to test the hypotheses.

Findings: Although professional accountants' presence is a significant explanatory variable, the results show no significant difference in IS use between family and non-family-owned firms. However, contrary to similar studies in countries without strong professional accounting bodies, the analysis suggests that professionalisation is a significant explanatory factor in the similarities found.

Contribution: By applying a more refined measure of professionalisation of accounting, this study provides a useful basis for further exploration of the professionalisation of the accounting function in family firms and links to IS use.

${ }^{1}$ Corresponding author: Catherine Batt, Department of Accounting, Copenhagen Business School, Denmark, Tel: +(45) 38152373, email address: caba.acc@cbs.dk 
Keywords: information systems (IS), accounting, family businesses, professionalisation.

\section{JEL codes: M41}

\section{Introduction}

Accounting and information systems (IS) typically bring structure and discipline to firms (Davila \& Foster, 2007). However, research suggests there is less use of accounting in family businesses, and information technology (IT) adoption is lower. IS's role in family business remains relatively unexplored. Much family business scholarship has focused on ascertaining the uniqueness (or not) of family businesses in different contexts. One difference is the apparent lack of professional management in family business, leading to less formal accounting and control systems (Hiebl et al., 2015; Senftlechner \& Hiebl, 2015; Songini \& Gnan, 2015). According to Rutherford et al. (2008), this difference is mainly due to the more informal and trusting nature of family businesses. It has been reported that the level of accounting and control increase as family firms professionalise (Giovannoni et al., 2011), indicating that professionalisation of management functions increases with training and/or additional qualifications - e.g., Salvato and Moores (2010), Songini et al. (2013), Prencipe et al. (2014), Senftlechner and Hiebl (2015).

Rapid development of IT in the past decade has made the use of IS ${ }^{1}$ and IS innovations ubiquitous in firm management (Sisay \& Birnberg, 2010). This includes Enterprise Resource Planning (ERP) systems, Business Intelligence, specialised accounting IS, and a host of other technologies - yielding a powerful source of competitive advantage (Porter \& Millar, 1985). IT is also a source of disruption, eroding entrenched advantages and creating new ones (Porter \& Millar, 1985; Marinagi et al., 2014;), thereby impacting firm performance (Cleary \& Quinn, 2016). Therefore, selecting, developing, and implementing the right IS is a critical management task with different maturity levels and performance implications (Guo et al., 2015). Research has shown that there is a difference between family and nonfamily businesses in adopting and using IT generally, with family businesses more resistant to adopting new IT and more conservative in its use (Ogbonna and Harris, 2005; Bruque \& Moyano, 2007; Kandel \& Hota, 2012).

Links between accounting and IT/IS are well established (Yigitbasioglu, 2016; Rikhardsson \& Yigitbasioglu, 2018;). The accounting function is often the primary user of IS in firms. Indeed, accounting characteristics have been shown to influence the use of IS, such as ERP systems, Business Intelligence, and specialised accounting systems (Rom \& Rohde, 2007; Vasarhelyi et al., 2009; Grabski et al., 2011; Yigitbasioglu, 2016; Rikhardsson \& Yigitbasioglu, 2018). Conversely, the 
implementation of new IS has also been shown to impact accounting practices (Rom \& Rohde, 2007; Sutton, 2010; Grabski et al., 2011; Sutton et al., 2016).

Two research questions are explored in this paper. Firstly, we aim to establish if the use of IS in family businesses differs significantly from non-family businesses? If so, factors may be identified - including accounting characteristics or certain characteristics of the accountants employed - which may guide family business owners to improve the use of IS in creating and sustaining competitive advantage and contributing to family business research. Given the importance of professionalisation in family business research, the second research question is, does professionalisation of accountants positively impact the use of IS, and is there a difference between family and non-family businesses? The professionalisation of accounting has been previously defined as university education. It has been shown that family ownership is negatively correlated with the firms' accountants holding a university degree (Hiebl et al., 2015; Hiebl \& Mayrleitner, 2019). However, the research focus has been on Germanic countries which do not have professional accounting bodies ${ }^{2}$ as in Anglo-Saxon countries. A literature review on accounting in family businesses and the adoption of IS was undertaken to frame the research questions and develop hypotheses. To collect data, a survey instrument was distributed to Irish SME. Ireland has many family-owned businesses and a strong accounting profession.

The paper is structured as follows, the next section highlights differences between family and non-family businesses, including accounting and IS used in a family business context. Then, our hypotheses are presented, followed by the methodology. This is followed by a presentation of the results and some discussion thereof.

\section{Literature review and hypothesis development}

\subsection{IS}

IS are usually classified as one of transaction processing, decision support and/or management information systems (Loudin \& Traver, 2012). As IS have become more integrated, it is difficult to examine one specific component in isolation. An integrated accounting system receives data from sales, purchasing and manufacturing models while delivering information to reporting and analytics modules (Grabski et al., 2011). Similarly, ERP systems enable firms to manage processes, resources, products, services, personnel, capital assets as an integrated application supporting many information processing needs - including accounting information (Rikhardsson \& Kræmmergaard, 2006; Grabski et al., 2011). While not all firms have an ERP solution, most have an accounting IS (Kanellou \& Spathis, 2013). Business Intelligence (BI) has also emerged as a separate solution type (Rikhardsson \& Yigitbasioglu, 2018). In smaller firms, developments such as cloud 
technology have made accounting software available to even the smallest business (Strauss et al., 2014), potentially improving performances (Cleary \& Quinn, 2016). Customer relationship management (CRM) solutions are more prevalent either as a part of ERP systems or a stand-alone solution ${ }^{3}$. Additionally, the use of continuous auditing technologies is increasing, particularly in data-intensive industries such as insurance (Byrnes et al., 2015).

\subsection{Family firms and use of IS}

A literature search was performed following Salvato and Moores' (2010) approach to mapping research on IS in family business. To capture as much literature as possible, a broad search of the Scopus and EBSCO databases was undertaken using the rubric "information systems" AND "family business" in all article fields. This yielded 112 matches. A manual inspection showed few papers addressing the adoption/use ${ }^{4}$ of IS and related determinants in family businesses. The most relevant are now summarised. Ogbonna \& Harris (2005) focused on IT's broad use in a family business over time, showing that culture, customer relations, business sector, and the tenure/age of employees impact IT's overall adoption. Bruque and Moyano (2007) suggested that small family businesses are often more reluctant to adopt novel IT than small non-family businesses. Kandel and Hota (2012) discussed factors that can impact IT adoption in family businesses in developing economies, including business maturity and culture. Finally, Barressi et al. (2012) focused specifically on family businesses in the health care sector and illustrated how family businesses can achieve success with IS implementation.

There appears to be a limited focus on IS use and application in family business literature, as it is difficult to determine from extant literature if the key premise of family business research holds: "that family firms are, in many respects, different from non-family firms" (Ibrahim \& McGuire, 2011). Thus, a review of the literature on IS adoption in small and medium-sized enterprises (SME) was conducted. While the family business and SME literature are two distinct branches, it is reasonably assumed that many family businesses are SME. We utilised the same search terms and sources as detailed earlier. Two key variables emerged from the search results as possible predictors of IS adoption: firm size and factors related to the Chief Executive Officer (CEO). On the first, as the costs of adopting some IS are significant, evidence showing larger firms are more inclined to invest (Thong \& Yap, 1995; Thong, 1999; Buonanno et al., 2005). Size is also a variable used in the family business literature and thus is included in our regression model later. The second key variable is related to the role of the CEO in SME. It appears that SME having a more innovative CEO are more likely to adopt IS (Thong \& Yap, 1995). This was also reported by Thong (1999), who additionally found that the IS knowledge of the CEO is a predictor of future IS adoption. A literature review on IS adoption in SME conducted by Parker et al. (2015) suggests that firm size remained a key factor in IS 
adoption - supporting its inclusion here (see later). There have been further studies in the broader IS literature exploring success factors in IS adoption. For example, Holland and Light (1999), Parr and Shanks (2000), and Umble et al. (2003) studied the critical success factors of ERP system implementations. A common finding was a need for top management support, similar to the CEO role suggested in the SME literature. More recently, Strauss et al. (2014) noted how cloud technology can reduce costs, allow access to technology that was previously the realm of large business, and is flexible in terms of services used. The effects of such developments have yet to be explored in a family business context - see Quinn (2017). Given this, and as we are not exploring IS adoption projects per se, we do not consider the role of top management or the CEO as a variable.

The literature reviewed also identified variables reflecting the complexity of the business environment in which firms operate in terms of competitive/market pressures (Thong \& Yap, 1995; Thong, 1999; Buonanno et al., 2005; Gahsemi et al., 2016;). These complexity variables are not all considered here, although we do capture elements of operational complexity by considering whether firms sell internationally. Furthermore, some literature addressed issues of IS maturity and its links to firm performance, although not in a family firm context (Wang \& Alam, 2007; Rao et al., 2015). IS maturity is determined by firms' capabilities in planning, controlling, and utilizing IS (Rao et al., 2015). IS maturity affects infrastructure decisions, and formalization of IS, leading to improved firm performance. A significant determinant of IS maturity is employee IT skills and competencies (Santhanam \& Hartono 2003).

\subsection{Family firms and accounting}

Some prior reviews are used to summarise reported differences in accounting in family businesses - Salvato and Moores (2010), Songini et al. (2013), Prencipe et al. (2014) and Senftlechner and Hiebl (2015). In the databases mentioned above, we also searched for papers published since 2015 using the terms "accounting in family business" and "accounting in family firms". An emphasis on management accounting in the literature could be expected given that financial accounting is similarly regulated for family and non-family businesses - although less onerously for smaller firms. It is also worth noting that whether financial accounting or management accounting, the data and information outputs and various processes and procedures within a business are encompassed within an IS.

Salvato and Moores (2010, p.194) presented their paper as "devoted to taking steps toward developing a comprehensive understanding of the specific features of accounting practices in family firms and an agenda for future research". They provided an overview of the literature on financial accounting, management accounting and auditing, reporting a total of 47 articles on the various components 
of accounting in family businesses. The majority focussed on financial accounting, with a heavy emphasis within quantitative research on the topic of earnings management. They noted much research was focused on published financial statements, which does not highlight family businesses' intricacies. From a management accounting context, they noted the need for more research.

Songini et al. (2013) conducted a more extensive literature review, also noting relatively few studies on management accounting. Based on these two literature reviews, management accounting topics covered included the presence of specific agency costs and resulting control mechanisms in family businesses; formal and informal management control practices; change in management accounting systems over the family life cycle; and professionalisation (of management accounting) of family businesses, and non-family Chief Financial Officers (CFO).

Prencipe et al. (2014) again confirmed the prevalence of financial accounting focused research and noted that "archival data are widely used, and most prominently in financial accounting studies, which is not surprising given the public availability of the data that allows researchers to track family relations, stock ownership and board positions to form proxy measures" (p. 378) and that "qualitative research seems significantly underutilised". Prencipe et al. (2014) also highlighted definitional issues around a family business and theoretical issues in emerging family business literature.

These reviews reveal a focus on financial accounting and were designed to be general. The review by Senftlechner and Hiebl (2015) focused on management accounting and control. Its sources were extensive, covering from 1985 to 2012. It confirmed the previously reported small number of studies on management accounting/control in family businesses. One general conclusion arising from it is that family businesses engage less with management accounting and control. However, the review also revealed that as a family business grows, management accounting and control systems become more similar to non-family businesses (Speckbacher \& Wentges, 2012). Senftlechner and Hiebl's (2015) review also noted that management accounting and control systems can improve communication of both the founders and families' values throughout the business. Furthermore, they highlighted the need for more management accounting research.

Within the literature covered by the reviews mentioned above, the management accounting and control issues addressed vary from a review of management accounting practices (Giovannoni et al., 2011) to the realisation that founding family involvement in top management teams results in fewer performance measures (Speckbacher \& Wentges, 2012). From a management accounting/control perspective, extant research suggests less of it in family businesses (FeldbauerDurstmuller et al., 2012), with greater similarities to non-family businesses as family 
businesses grow (Neubauer et al., 2012). From the literature, it is possible to identify some common variables that have been shown to be determinants of management accounting in family firms which may be considered determinants of IS usage. Professionalisation of accounting and firm size are two such variables (Lutz et al., 2010; Hiebl et al., 2012; Neubauer et al., 2012; Stewart and Hitt, 2012; Dekker et al., 2013) and both are utilised here. Firm size has been noted earlier and the professionalisation of family businesses is considered in the context of the increasing professionalisation of the CFO positions (as a professionally qualified accountant).

\subsection{Hypotheses development}

The literature review suggests there is potential to study the peculiarities (or otherwise) of IS adoption/use in family businesses. Given it also suggests differences in accounting in family businesses and an apparent lack of studies in IS, the research questions earlier focus on whether the use of IS in family businesses differs, and could accounting characteristics and the professionalisation of the accounting function be an explanatory variable? The limited relevant IS literature suggests IS/IT have lower usage in small (and family firms). The accounting literature referred to earlier suggests increased professionalisation of accounting practice implies more complex and formal management accounting (Quinn \& Hiebl, 2018), which may link to an increased level of technology usage.

The concept of a professional accountant has been noted in prior family business literature (Hiebl, 2014). The inclusion of accounting professionalisation raises an interesting point, as understanding an accounting profession is contextual. In a typical Anglo-Saxon context, an accountant is a professional on completing a course of study and work-based experience with a legally recognised accounting body. They must also undertake mandatory continuing professional development (Murphy \& Quinn, 2018). In contrast, in Germanic and Scandinavian countries, only auditors are subject to regulation and certification. Studies which note the professionalisation of accounting in family businesses have not specifically defined what constitutes a professional accountant (Lutz et al., 2010; Stewart \& Hitt, 2012; Dekker et al., 2013). Professionalisation as a variable has been operationalised as the accountant's education level, such as having a university education (Hiebl et al., 2015; Hiebl \& Mayrleitner, 2019). In a family business, the notion of stewardship may imply professionals engage more in "prosocial and collectivist behaviors than [..] economic, individualist, and self-serving behavior" (Craig \& Moores, 2015, p.146). However, in an Anglo-Saxon context, professional accountants also have a duty to serve the public interest (e.g., O'Regan \& Killian, 2014). This could be equated to prosocial and collective behaviour as per Craig and Moores (2015), with public interest paramount to any family interests. Thus, here, the professionalisation (or otherwise) of accounting in a family business cannot be viewed as being associated with family interests, even if accounting positions - such as CFO - are held by family 
members. As noted above, the literature suggests a positive relationship between the characteristics of accounting and professionalisation in family firms, which implies a reliance upon and use of IS.

Other potential influencing factors, both family and non-family related have been noted in the literature (see earlier). Firm size has been reported and is considered here as a control variable. Two other control variables used here are firm complexity (measured by the level of international activity in sales proportion terms (Hitt et al., 1997, Gómez-Mejia et al., 2010)); and family firm age (the generation of the controlling family where 25 year equates to one generation (Blanco-Mazagatos et al., 2007)).

Based on the above and the earlier literature, the following two hypotheses are posed to address the research questions:

H1: IS usage is lower in family firms compared to non-family firms.

$\mathrm{H} 2$ : The use of IS in family firms is positively associated with the professionalisation of accounting.

\section{Methodology}

\subsection{Research context}

The study context is Irish SME, of which family businesses are a substantial subset - it is estimated that $70-75 \%$ of all businesses in Ireland are family owned ${ }^{5}$. The data source was the FAME database, which provides company data for the largest 2.6 million Irish and United Kingdom (UK) companies. Cognisant of the exploratory nature of this study, coupled with limited prior research, we adopted the search criteria to refine the sample population. First, non-quoted Irish-based firms, with a trading address in the Republic of Ireland, whose annual turnover was greater than $€ 5$ million were included. While this excludes many smaller firms, it was a deliberate choice, as due to their size, this cohort of firms would be unlikely to have formal accounting functions and/or professional managers (Hiebl et al., 2015), and thus less likely to have more formalised IS. This annual turnover criterion implies some micro-firms are included based on the European Union (EU) definition ${ }^{6}$. Second, only firms with more than 50\% Irish-owned shareholdings were included to have a relatively homogenous grouping in terms of business outlook and culture. Finally, firms with more than ten full-time permanent employees were included, as again, firms with less employees are more likely to have rudimentary IS. Based on these criteria, the initial dataset was 456 firms. To retain a focus on active and more traditional companies, holding companies, financial services firms and dormant companies were excluded, giving a revised dataset of 426 firms. 


\subsection{Data collection}

A questionnaire was developed based on Rikhardsson et al. (2012), which was used in Icelandic SME for similar research objectives. Some amendments were made, resulting in a questionnaire with 67 questions across seven areas: organisation background, costing methods, budgeting, internal controls and risk assessment, performance management, IS and the organisation of the accounting/finance function. The survey was piloted with academics and financial executives, and any feedback was incorporated ${ }^{7}$ within the final questionnaire.

\subsection{Variable measurement}

The survey was distributed electronically to the CFO (or equivalent) of the sample firms. An inability to obtain some email addresses reduced the final sample population to 361 firms. From this, a total of 205 (57\%) responses were generated, with $108(30 \%)$ respondents completing the survey. This response rate is higher than other studies in management accounting in an Irish context (Quinn et al., 2017) and similar to the response rates in management accounting research reported by Hiebl and Richter (2018). A t-test was used to ensure no difference between respondents and non-respondents and to compare early and late respondents, with no significant differences identified. The responses consisted of 70 family-owned businesses and 38 non-family. While this is not a large sample, it is of comparable size to prior studies in management accounting (van der Stede et al., 2003), which in some cases have lower samples. To operationalise the hypotheses, six sets of IS-based questions and two sets of descriptive questions about the organisations/respondents were used. To identify family, respondents were provided with the following definition "Family-owned is defined as family members holding more than $50 \%$ of shares or having majority control of the Board of Directors" - and were asked to indicate if they considered their firm as family/non-family. This basic definition was deemed preferable given the relatively novel nature of this study. To measure the organisation's age, participants were asked the founding year of the firm. The industry was categorised according to a list of 17 industries (including an "Other please specify"), respondents choosing one option. Turnover of the most recent financial year was requested using a five-point Likert scale where $1=<€ 10 \mathrm{~m} ; 2=$ $\epsilon 11-20 \mathrm{~m} ; 3=\epsilon 21-50 \mathrm{~m} ; 4=\epsilon 51-100 \mathrm{~m}$, and $5=>\epsilon 101 \mathrm{~m}$. To measure the level of internationalization, respondents were asked to indicate what percentage of this turnover was generated outside of Ireland on a seven-point Likert scale where $1=1$ $10 \% ; 2=11-20 \% ; 3=21-30 \% ; 4=31-40 \% ; 5=41-50 \% ; 6=>50 \%$; and $7=$ All in Ireland. To capture the level of professionalisation, respondents were asked to confirm their level of education ranging from an undergraduate degree to a $\mathrm{PhD}$ degree (as per Hiebl et al. 2015), and to indicate if they were a professionally qualified accountant (not captured by Hiebl et al., 2015). The latter is the variable used here to capture professionalisation. We also gathered information on the 
seniority of respondents in their current position and the organisation as a whole measured on a 5 -point Likert scale from $1=$ less than a year ranging to $5=$ more than 10 years. As noted earlier, in a typical Anglo-Saxon contest, an accountant as member of a professional accounting body is expected to serve the profession and public interest, and this would override any family interest. Thus, we have not questioned whether the respondents are family member. Finally, respondents age and gender age were requested, the former on a five-point Likert scale ranging from $1=$ $18-24$ to $5=65+$.

On IS, nine questions were used. The first question measured how existing IS met the information needs of managers on a five-point Likert scale ranging from $1=N o t$ well at all to $5=$ Extremely well. Respondents were then asked if the organisation had a BI system and/or ERP in place, using a four-point Likert scale where:1 = I don't know; $2=N o ; 3=$ Used/updated more than 3 years; $4=$ Used/updated in the last 1-3 years. To measure the use of BI, a list of seven different purposes was offered - general reporting, financial analysis, market analysis, risk analysis, managers dashboard, planning and budgeting, operational control. Each participant was asked to rank these purposes from $1=$ most important to $7=$ least important . Regarding ERP systems, participants were asked what business processes were supported by the ERP system. Based on a list of eight different processes (finance, production, purchase, sales, services, quality control, budgeting, and payroll/HR) respondents had to select all applicable. Finally, respondents were asked to grade on a 6-point Likert scale the use of ten different technologies (see later) in their organisations, ranging from "Portal access to customers" to "Social media at work". Each technology was graded from: $1=$ I don't know; $2=$ No longer used; $3=$ No interest in using; $4=$ Some interest in use; $5=$ Strong interest in use; and $6=$ In use.

To capture data on accounting, respondents were asked to rank the importance of various tasks/techniques within the accounting function including costs analysis, budgeting, variance analysis, internal control, and performance measurement, and secondly; the importance of accounting staff having knowledge of certain areas including IS. These two questions required a ranking on a five-point Likert scale from 1 = Very important to 5 = Very unimportant .

\section{Results}

\subsection{Descriptive statistics}

As mentioned in Section 4.2, the sample data resulting from our survey is composed of $64.8 \%(n=70)$ family-owned businesses, $35.2 \%(n=38)$ non-family. All businesses were founded between 1900 and 2010, averaging at 40 years old. Thirty industry sectors were represented (see Table 1) with the retail sector providing the 
highest number of responses (11.1\%), followed by construction (9.3\%), manufacturing $(9.3 \%)$ and transport (8.3\%). An "other" category included the motor industry, distribution, education and hospitality.

Seventy-two firms $(72 \%)$ reported a minimum turnover between $€ 11$ - $€ 50$ million, thirty-one firms (28.7\%) above $€ 50$ million, with 13 (12\%) above $€ 100$ million. Five firms $(4.6 \%)$ reported a turnover of $€ 10$ million or less. Regarding staff numbers, $68 \%$ reported having a minimum number of permanent and full-time staff employed in Ireland of between 51 and 250 employees. These figures reveal that approximately $67 \%$ of respondent businesses can be considered "medium" size under EU SME criteria (turnover $€ 10$ - 50 million). Of the family businesses $(n=70)$, four reported annual turnovers of less than $€ 10$ million, while 14 reported a turnover greater than $€ 50$ million. Thus, 52 (74\%) of the family businesses are medium-sized or smaller based on a turnover criterion.

Table 1 - Sectors represented by sample companies

\begin{tabular}{lcc} 
& \multicolumn{2}{c}{ Respondents } \\
\cline { 2 - 3 } & n & $\mathbf{\%}$ \\
\hline Other & 19 & 17.6 \\
Retail & 12 & 11.1 \\
Construction & 10 & 9.3 \\
Manufacturing & 10 & 9.3 \\
Transport & 9 & 8.3 \\
Food & 7 & 6.5 \\
Agribusiness & 7 & 6.5 \\
Health & 6 & 5.6 \\
Energy & 5 & 4.6 \\
Professional services & 4 & 3.7 \\
Pharma & 4 & 3.7 \\
Financial services & 3 & 2.8 \\
Communication & 3 & 2.8 \\
Technology & 3 & 2.8 \\
Tourism & 3 & 2.8 \\
Media and marketing & 2 & 1.9 \\
Property & 1 & 0.9 \\
\hline
\end{tabular}

On the respondents, $78 \%(n=84)$ were male while $22 \%(n=24)$ female. On their highest level of third-level education, 37\% $(n=40)$ indicated an undergraduate degree, $39 \%(n=42)$ a Master's level degree and 3\% $(n=3)$ a PhD degree. For $29 \%$ $(n=31)$ of respondents, the average length of time in their current position is between 5 and 10 years, with $38 \%$ over 10 years. The average age of $60 \%$ of respondents $(n=65)$ was between 35 and 50 years old, whereas, for the 50-65 age bracket, the figure was $32 \%(n=35)$. Membership of a professional accounting body was confirmed by $82 \%(n=89)$ of respondents. 
Regarding ERP systems, $59.4 \%(n=57)$ claimed no ERP systems, $36 \%(n=39)$ stated use of ERP systems. Of the latter, 18 companies responded to what processes were supported by their ERP, with $33.3 \%(n=6)$ noting it supported finance processes. Collectively, 89 companies indicated use of BI with $34.8 \%(n=31)$ saying they had no BI solution, while $53.7 \%(n=58)$ of companies claimed to be using such a solution. On prioritising the use of BI solutions, 77 companies responded, and of those, $27 \%(n=29)$ placed general reporting as the first priority, with financial analysis second at $18.5 \%(n=20)$.

\subsection{Hypothesis-testing}

H1 proposed a difference in the IS use of family and non-family businesses. Given differences in accounting - as reported in the family business literature - it is reasonable to consider family and non-family businesses as independent samples. Using SPSS, we used the (non-parametric) Mann-Whitney test to analyse the difference between these two groups. The test analysed the difference on 22 variables, and the significant results are shown in Table 2.

Table 2 - Mann-Whitney test of IS variables, family v non-family businesses

\begin{tabular}{|c|c|c|c|c|c|c|c|}
\hline & $\begin{array}{c}\text { Family- } \\
\text { owned }\end{array}$ & $\mathbf{N}$ & $\begin{array}{l}\text { Mean } \\
\text { Rank }\end{array}$ & $\begin{array}{l}\text { Sum of } \\
\text { Ranks }\end{array}$ & $\mathbf{U}$ & $\mathbf{Z}$ & $\mathbf{p}$ \\
\hline \multirow[t]{3}{*}{$\begin{array}{l}\text { Business } \\
\text { intelligence (BI) } \\
\text { system in use? }\end{array}$} & Yes & 60 & 40.45 & 2427.00 & & & \\
\hline & No & 29 & 54.41 & 1578.00 & & - & \\
\hline & Total & 89 & & & 597.000 & 2.548 & $.011 * *$ \\
\hline \multirow[t]{2}{*}{$\begin{array}{l}\text { BI is used for } \\
\text { planning and } \\
\text { budgeting }\end{array}$} & Yes & 70 & 59.55 & 4168.50 & & & \\
\hline & No & 38 & 45.20 & 1717.50 & & - & \\
\hline \multirow[t]{3}{*}{$\begin{array}{l}\text { We have access to } \\
\text { systems via cloud } \\
\text { technologies }\end{array}$} & Total & 108 & 45.63 & 2783.50 & 976.500 & 2.318 & $.020 * *$ \\
\hline & No & 36 & 54.71 & 1969.50 & & & \\
\hline & Total & 97 & & & 892.500 & 1.717 & $.086^{* *}$ \\
\hline
\end{tabular}

* significant at $5 \%$ level

** significant at $10 \%$ level

As per Table 2, only three items show significant differences between family and non-family businesses, indicating little support for H1. In total, $56 \%(n=58)$ of the 
respondents reported using a BI system (35 family, 23 non-family). The MannWhitney test indicated significant difference $(U=597, p=.011)$. in the use of $B I$ for family businesses $(\mathrm{Mdn}=42)$ than non-family businesses $(\mathrm{Mdn}=12)$. A significant difference was also observed on the BI planning and budgeting item $(\mathrm{U}=976.5$, $\mathrm{p}=.020$ ). The average ranking for family businesses was 4.46 , in comparison to 3.87 for non-family businesses. The Mann-Whitney test indicated that the importance of $\mathrm{BI}$ in planning and budgeting was greater for family businesses $(\mathrm{Mdn}=31)$ than for non-family businesses $(\mathrm{Mdn}=23)$. This suggests $\mathrm{BI}$ use for planning and budgeting is ranked more importantly in non-family businesses. This partly supports prior literature on management accounting (budgeting specifically) being less of a feature in family businesses. A significant difference was also observed on the use of cloud technology with $(\mathrm{Mdn}=61)$ for. family businesses and $(\mathrm{Mdn}=31)$ than for nonfamily businesses, $(\mathrm{U}=892.5, \mathrm{p}=.086)$.

The survey also probed the importance of management accounting characteristics (cost analysis, budgeting, variance analysis, internal control, and performance management). The Mann-Whitney tests indicated that variance analysis was significantly more important $(\mathrm{U}=926.5, \mathrm{p}=.007)$ for family businesses $(\mathrm{Mdn}=53)$ than for non-family businesses $(\mathrm{Mdn}=20)$. It also showed that the importance of internal control was significantly more important $(U=931.5, p=.006)$ for family businesses $(\mathrm{Mdn}=68)$ than for non-family businesses $(\mathrm{Mdn}=38)$. Finally, budgeting was more important for family businesses $(\mathrm{Mdn}=70)$ than for non-family businesses $(\mathrm{Mdn}=38), \mathrm{U}=785.5, \mathrm{p}>.01$.

\subsection{Regression and multivariate analysis}

$\mathrm{H} 2$ suggests that the use of IS in family businesses is positively associated with the level of professionalisation. A logit regression was employed to test the hypothesis, following a multiplicative model:

where:

$$
\mathrm{IS}_{\mathrm{n}}=\alpha_{0}+\alpha_{1} \mathrm{FB}+\alpha_{2} \text { Prof }+\alpha_{3} \text { Size }+\alpha 4 \text { Int }
$$

IS $_{\mathrm{n}}=\quad$ variables IS1 to IS6 per Table 1

$\mathrm{FB}=0$ if non-family business, 1 if family business (family control by majority shareholding or control of board)

Prof $=$ Respondent is member of a professional accounting body

Size $=0$ if firm size is small (turnover $<€ 10 \mathrm{~m}$ ), 1 if medium or larger (turnover $>€ 10 \mathrm{~m}$ )

Int $=$ Internationality if percentage of turnover exported $>30 \%$

To measure the goodness of fit of the logistic model, a Hosmer-Lemeshow (H-L) test was run, yielding a $\chi^{2}(7)$ of 3.612 and was insignificant $(\mathrm{p}>.05)$. As there are more than two explanatory variables within the above regression model, 
multicollinearity is a potential issue. Table 3 reports variance inflation factor (VIF) and Pearson correlations, suggesting multicollinearity is not an issue. The regression model was tested as logit, or ordinal, based upon the nature of the dependent variable. A logit regression model was applied to variables IS2 and IS3. The variable IS4 relates to various types of technologies and was subdivided into ten items (IS4a IS4j), one for each question in the survey. A total of fifteen regressions were tested and a summary of the results is shown in Table 4.

Table 3 - Pearson correlation

\begin{tabular}{|c|c|c|c|c|c|c|}
\hline & & & 1 & 2 & 3 & 4 \\
\hline \multirow[t]{3}{*}{1} & Family owned & Pearson Correlation & 1 & & & \\
\hline & & Sig. (2-tailed) & & & & \\
\hline & & $\mathrm{N}$ & 108 & & & \\
\hline \multirow[t]{3}{*}{2} & Professionalisation & Pearson Correlation & -.102 & 1 & & \\
\hline & & Sig. (2-tailed) & .295 & & & \\
\hline & & $\mathrm{N}$ & 108 & 108 & & \\
\hline \multirow[t]{3}{*}{3} & Size & Pearson Correlation & -.007 & -045 & 1 & \\
\hline & & Sig. (2-tailed) & .945 & .641 & & \\
\hline & & $\mathrm{N}$ & 108 & 108 & 108 & \\
\hline \multirow[t]{3}{*}{4} & Internationalisation & Pearson Correlation & -.020 & .007 & .114 & 1 \\
\hline & & Sig. (2-tailed) & .834 & .941 & .239 & \\
\hline & & $\mathrm{N}$ & 108 & 108 & 108 & 108 \\
\hline
\end{tabular}

Table 4 - Regression model significant differences

\begin{tabular}{|c|c|c|c|c|c|c|}
\hline Variable & Description & FB & Prof & Size & Int & $\begin{array}{c}\text { Pseudo } \\
\mathbf{R}^{2}\end{array}$ \\
\hline IS 1 & $\begin{array}{l}\text { Information systems } \\
\text { meet management needs }\end{array}$ & 0.810 & $0.028 *$ & 0.945 & 0.979 & .097 \\
\hline IS2 & $\begin{array}{l}\text { Business intelligence } \\
\text { (BI) system in use }\end{array}$ & 0.424 & $.027 *$ & .595 & .970 & .081 \\
\hline IS3 & ERP system in use & 0.592 & .252 & .515 & $.094 * *$ & .057 \\
\hline IS4a & Uses a customer portal & 0.106 & $.057 * *$ & $.084 * *$ & $.083 * *$ & .109 \\
\hline IS4b & Uses a cloud technology & $0.044 *$ & $.016 *$ & .133 & .198 & .147 \\
\hline IS4c & $\begin{array}{l}\text { Uses a continuous } \\
\text { auditing technology }\end{array}$ & $0.099 * *$ & .375 & .543 & .143 & .061 \\
\hline
\end{tabular}




\begin{tabular}{rlrrrrr}
\hline Variable & \multicolumn{1}{c}{ Description } & FB & Prof & Size & Int & $\begin{array}{c}\text { Pseudo } \\
\mathbf{R}^{2}\end{array}$ \\
\hline IS4d & Uses a data warehouse & 0.318 & $\mathbf{. 0 0 2 *}$ & $\mathbf{. 0 0 8 *}$ & .814 & .167 \\
IS4e & Uses a CRM system & 0.540 & $\mathbf{. 0 0 1 *}$ & $.027^{*}$ & .343 & .175 \\
IS4f & $\begin{array}{l}\text { Uses a content } \\
\text { management solution }\end{array}$ & 0.821 & $\mathbf{. 0 0 2 *}$ & .651 & .222 & .125 \\
IS4g & $\begin{array}{l}\text { Uses a quality control } \\
\text { information system }\end{array}$ & 0.377 & $\mathbf{. 0 2 8 *}$ & .315 & .134 & .129 \\
IS4h & $\begin{array}{l}\text { Has an online business } \\
\text { presence }\end{array}$ & 0.640 & $\mathbf{. 0 2 4 *}$ & .241 & .359 & .072 \\
IS4i & $\begin{array}{l}\text { Uses a time recording } \\
\text { system }\end{array}$ & 0.352 & .108 & .739 & .851 & .050 \\
IS4j & $\begin{array}{l}\text { Uses social media for } \\
\text { business }\end{array}$ & 0.161 & .460 & .305 & $.069 * *$ & .061 \\
IS5 & $\begin{array}{l}\text { Satisfied with } \\
\text { information systems }\end{array}$ & 0.768 & 512 & 246 & 233 & .073 \\
IS6 & $\begin{array}{l}\text { Likely that information } \\
\text { systems will change in } \\
\text { the next 1-3 years }\end{array}$ & 0.318 & 760 & 510 & 311 & .059 \\
\hline
\end{tabular}

* significant at $5 \%$ level

** significant at $10 \%$ level

As Table 4 illustrates, nine of the fifteen dependent variables are statistically significant with the professionalisation of accounting (Prof) at either 5\% or $10 \%$. Thus, there is partial support for H2. Table 4 also shows that Size and Int may be significant variables in some cases. Int is statistically significant for IS3, which queries respondents on the use of ERP.

A statistically significant relationship is revealed for two IS variables and the family nature of the business, cloud technology and continuous auditing technologies. In both cases, the coefficient is negative. As the $F B$ variable is dichotomous, the negative coefficient implies a stronger tendency of the regression model to predict outcomes when the $F B$ value is 0 , i.e., it is statistically more likely than non-family businesses use cloud computing and continuous auditing technologies.

Summarising the regression model results, we cannot suggest that the family status of a business is a predictor of the level of IS use. This supports the earlier results 
from the Mann Whitney test indicating that we cannot support H1. As Table 4 illustrates, the $\mathrm{R}^{2}$ values relevant to this study range from $17.5 \%$ for IS4e (uses a CRM system) to $5 \%$ for IS4i (uses a time recording system), demonstrating that certain models are better predictors of the expected outcome.

As mentioned earlier, extant family business literature highlights increasing professionalisation of family firms through the engagement of non-family professionals - such as CFOs and/or professional accountants. Based on the tests and models depicted, there is much similarity between the two types of business in Ireland, which raises a question as to why. One potential reason is a strong prevalence of professionally qualified accountants among respondents - $82 \%$ in total. The distribution of professionally qualified accountants across family and nonfamily businesses in the sample is similar, suggesting this high presence of professional accountants in both may be an explanatory factor. To investigate the potential effect of professional accountants in the sample firms, we conducted an $e x$ post multivariate test (one-way MANOVA) for each of the IS variables shown in Table 4. FB and Prof were set as the dependent variables, with each variable in Table 4 as the fixed factor. The results of these tests show no statistical difference for IS3 (ERP system in use), IS4c (uses a continuous auditing technology), IS5 (satisfied with information systems) and IS6 (likely that information systems will change in the next 1-3 years) as per Table 4 . All other variables reveal Prof as being statistically significant - IS1 (information systems meet management needs) and IS4j (uses social media for business) at $10 \%$ confidence; IS2 (business intelligence (BI) system in use) and IS4b (uses a cloud technology) at 5\%; all others at 1\%. None reveal $F B$ as significant. Thus, considering the statistical tests conducted, there is partial support for $\mathrm{H} 2$. However, the analysis suggests that the presence of professional qualified accountants is significantly related to the majority of IS variables utilised here, whether in family businesses or non-family businesses.

\section{Discussion and concluding comments}

This paper aims to provide empirical evidence on differences in IS usage between family and non-family businesses. It was hypothesised that there would be less use of IS in family businesses (H1), and that IS use is related to the professionalisation of accounting (H2). Based on a sample of Irish family businesses we did not obtain support for $\mathrm{H} 1$, and partial support for $\mathrm{H} 2$. There was a high prevalence of professional accountants in both family and non-family businesses throughout the sample firms. Such professional accounting staff might be expected to be more prevalent in medium-sized firms, but interestingly our regression model did not reveal firm size nor internationality as a general predictor of IS use. This contrasts with Songini and Gnan (2015) and Hiebl et al. (2015) who reported a positive relationship between firm size and agency control mechanisms such as accounting and IS. Additionally, the fact that firm size is not a predictor of IS use also partially 
contradicts the suggestions by Speckbacher and Wentges (2012) and Senftlechner and Hiebl (2015) that increasing size means more use of IS.

The fact that our data offers some support for $\mathrm{H} 2$ is consistent with prior literature on the effects of professional accountants in a family business context (Hiebl et al., 2015; Songini \& Gnan, 2015). However, the context of professional presented here is different - as outlined earlier. Our findings suggest that professional accountants - members of professional accounting bodies - may be equalisers of the use of IS for management decision-making regardless of firm type or size. From a different perspective, professional accountants seem to be able to overcome or adapt to the unique features of a family business in terms of the information and accounting systems needed. This could indicate that professional accountants are a major influencer on the IS maturity of smaller firms. The accounting profession, and professional accounting bodies, do emphasise the use of information technology in supporting decision-making, planning, control, and performance measurement. Increasing IS maturity is highly dependent on these skills being introduced in firms (Santhanam \& Hartono, 2003; Rao et al., 2015). Our results indicate that professionalisation of accounting and professional accountants' presence in firms has an important role to play here.

This study suggests that professional accountants may be a key factor in explaining the level of IS in a family business and that "familiness" is a less important factor. This raises questions for theoretical constructs in the family business literature, which we could summarise as the non-economic interests of the family (GómezMejía et al., 2007). That is not to say that these constructs are invalid, but in certain contexts, they may be less "influencing" than others - here, the power of a profession to promote accounting practices and supporting IS regardless of firm type. However, our findings may be context specific.

There is also an ongoing problem assessing IS (and/or technology in general) in businesses (family or non-family) given the rapid pace of technical change, especially as technical innovation often has administrative and accounting innovation implications (Sisay \& Birnberg, 2010). This should not discourage us from researching further and linking more in-depth knowledge of IS to extant theoretical constructs on family business. Of course, there are also implications of our findings for family business practitioners. The thrust of this study's findings is that professional accountants are "equalisers" of knowledge and expertise across family and non-family businesses. Thus, it may be suggested that family businesses hire a professional accountant to improve their IS, and ultimately their decisionmaking capabilities. At a broader level, in contexts where an (Anglo-Saxon style) accounting profession is weak, educators and/or policymakers may wish to explore how such a gap could be filled to benefit a family business. 
With its associated certifications and accreditations, an accounting profession is what an institutionalist such as Scott (2014) refer to as a "pillar" of institutions. Institutional research has been applied to accounting at the organisation level in family businesses (Quinn \& Hiebl, 2018) and family business in general (Soleimanof et al., 2018). Institutions also exist at broader levels, such as the organisational field and society itself (Scott, 2014). As suggested by the findings here, a normative influence of the accounting profession (at least in an Anglo-Saxon context) seems to be exerted on family (and non-family) business. Parada et al. (2010) explored a voluntary professional association as a carrier of institutionalisation processes of governance, and the evidence suggests similar conforming influences on IS, i.e., certain institutional forces have the same effect on businesses, family or non-family. To some extent, this is contrary to the oft-cited uniqueness of family businesses. For example, Soleimanof et al. (2018, p.36) suggested an avenue for future institutionalbased research was "family firms' distinct ways of compliance with formal institutions and deviations from adopting customary responses to formal institutions due to family firms' particularism". From our findings and context, the particularism they refer to is not revealed.

This study is a relatively isolated one. While studies exploring the "familiness" of firms in a more extensive are recommended, it is suggested that more studies are needed to build a reasonable body of knowledge on the type of IS in family businesses. This, we believe, is necessary before we begin to explore how IS (or technology in general) may affect the architecture, governance, entrepreneurship, and stewardship (AGES framework) of, and in, family businesses (Volkoff et al., 2007; Quinn \& Hiebl, 2018), and likewise how "familiness" and family priorities (such as non-economic goals) may affect technology and IS. It is not inconceivable that digitalisation of family businesses may allow them to be more entrepreneurial and survive longer, or at least adapt to the fast-paced business environment; that digitalisation of family businesses and a more formal systematic set of access controls and permission within more complex IS can support firm governance, and that digitalisation of family businesses can provide better data and information to support family interests. Such thoughts may lead to interesting future research.

The role of the human actor has not been explored in this study, and this is often relevant in a family business context. For example, certain family members could play a role in the development of IS in a family business, alongside a professional accountant, or as a dual role, i.e., as a professional accountant and a family member. In such cases, it would be interesting to explore (most likely using qualitative research methods) how such role conflicts would affect the use of IS in a family business.

This research has some general limitations. Naturally, the limitations of survey research methods apply, but the context of the survey - Ireland, a country with a 
strong accounting profession - may be a contextual factor affecting the results. Future studies in other contexts would be useful. Also, the survey questions were designed to obtain a general overview of the state of IS in the respondent businesses. This may be concealing nuances and detail, but we would argue a detailed (e.g., qualitative) study at an early stage of exploring IS in family businesses is less preferable. Additionally, as the research was conducted solely within the Irish SME context, the findings may not be generalizable. The study also used CFO (or equivalent) perceptions captured by Likert scales. This accumulation of dependent and independent variables from a single source may lead to common method bias (Chong $\&$ Chong, 1997). Future research could attempt to elicit responses from a range of employees within each firm to overcome this. Finally, we use a basic understanding of a family business. There are other subtler and more complicated definitions of a family business, and while potentially better, were avoided in this study given its relative novelty.

\section{Notes:}

${ }^{1}$ Here defined as the hardware and software developed for a specific purpose and operated by a group of users - see also Laudon and Laudon (2014).

${ }^{2} \mathrm{We}$ are not referring to certified auditors who are often state authorised.

${ }^{3}$ https://www.gartner.com/en/documents/3938684/magic-quadrant-for-the-crm-customerengagement-center

${ }^{4}$ While adopting a technology/system does not necessarily imply its full use, the terms adoption and use are used interchangeably in this study.

${ }^{5}$ See for example familybusiness.ie.

${ }^{6}$ Annual turnover of less than $€ 10$ million

${ }^{7}$ A copy of the survey is available upon request from the authors. 


\section{References}

Blanco-Mazagatos, V., de Quevedo-Puente, E. \& Castrillo, L. (2007) "The trade-off between financial resources and agency costs in the family business: An exploratory study", Family Business Review, vol. 20, no. 3: 199-213.

Bruque, S. \& Moyano, J. (2007) "Organisational determinants of information technology adoption and implementation in SMEs: The case of family and cooperative firms"”, Technovation, vol. 27, no. 5: 241-253.

Buonanno, G., Faverio, P., Pigni, F., Ravarini, A., Sciuto, D. \& Tagliavini, M. (2005) "Factors affecting ERP system adoption - A comparative analysis between SMEs and large companies", Journal of Enterprise Information Management, vol. 18 , no. 4: 384-426.

Byrnes, P., Ames, B. \& Vasarhelyi, M. A. (2015) "The Current state of continuous auditing and continuous monitoring", in AICPA (Ed.), Audit Analytics and Continuous Audit: Looking Towards the Future, American Institute of Certified Accountants, New York: 53-70.

Chong, V. K. \& Chong, K. M. (1997) "Strategic Choices, Environmental Uncertainty and SBU Performance: A Note on the Intervening Role of Management Accounting Systems", Accounting \& Business Research, vol. 27, no. 4: 268-276.

Cleary, P. \& Quinn, M. (2016) "Intellectual capital and business performance", Journal of Intellectual Capital, vol. 17, no. 2: 255 - 278.

Craig, J. B. \& Moores, K. (2015) "The A-GES Framework: Understanding the family business difference", in Newbert, S.L. (Ed.), Small business in a global economy: Creating and managing successful organizations, Santa Barbara, CA: Praeger: 123-154.

David, G.K., Lawrence, L.K. \& Keith, E.M. (1998) Applied Regression Analysis and Other Multivariate Methods, Boston, MA: Duxbery Press.

Davila, A. \& Foster, G. (2007) "Management Control Systems in Early-Stage Startup Companies", Accounting Review, vol. 82: 907-937.

Dekker, J. C., Lybaert, N., Steijvers, T., Depaire, B. \& Mercken, R. (2013) "Family firm types based on the professionalization construct: Exploratory research", Family Business Review, vol. 26, no. 1: 81-99.

Dormann, C.F., Elith, J., Bacher, S., Buchmann, C., Carl, G., Carre, G., Marquez, J.R.G., Gruber, B., Lafourcade, B., Leitao, P.J. \& Munkemuller, T. (2013) "Collinearity: a review of methods to deal with it and a simulation study evaluating their performance", Ecography, vol. 36, no. 1: 27-46.

Feldbauer-Durstmuller, B., Duller, C. \& Greiling, D. (2012) "Strategic management accounting in Austrian family firms", International Journal of Business Research, vol. 12, no. 1: 26-42.

Giovannoni, E., Maraghini, M. P. \& Riccaboni, A. (2011) "Transmitting knowledge across generations: The role of management accounting practices", Family Business Review, vol. 24, no. 2: 126-150.

Gómez-Mejia, L.R., Makri, M. \& Kintana, M.L. (2010) "Diversification decisions in family-controlled firms. Journal of Management Studies", vol. 47, no. 2: 223-252.

Gómez-Mejía, L. R., Haynes, K. T., Núñez-Nickel, M., Jacobson, K. J. \& MoyanoFuentes, J. (2007) "Socioemotional wealth and business risks in familycontrolled firms: Evidence from Spanish olive oil mills", Administrative Science Quarterly, vol. 52, no. 1: 106-137.

Grabski, S., Leech, S. \& Schmidt, P. (2011) "A review of ERP research: A future agenda for accounting information systems", Journal of Information Systems, vol. 25 , no. 1: 37-78. 
Guo, Ken H., Rao, Y. \& Chen, Y. (2015) "Information Systems Maturity, Knowledge Sharing, and Firm Performance", International Journal of Accounting \& Information Management, vol. 23, no. 2: 106-27.

Hair, J., Black, W., Babin, B.Y.A., Anderson, R. \& Tatham, R. (2010) “Multivariate Data Analysis. A Global Perspective”, New Jersey: Pearson Prentice Hall.

Hiebl, M. R. W. (2014) "A finance professional who understands the family: Family firms' specific requirements for non-family chief financial officers", Review of Managerial Science, vol. 8, no. 4: 465-494.

Hiebl, M. R.W. \& Richter, J. F. (2018) "Response rates in management accounting survey research", Journal of Management Accounting Research, vol. 30, no. 2: $59-79$.

Hiebl, M. R. W., Duller C., Feldbauer-Durstmüller, B. \& Ulrich, P. (2015) "Family influence and management accounting usage: Findings from Germany and Austria", Schmalenbach Business Review, vol. 67: 368-404.

Hiebl, M. R. W., Duller, C. \& Feldbauer-Durstmüller, B. (2012) "Do management accountants play a different role in family firms? Empirical evidence on management accountants' qualification and roles in family and non-family firms", International Journal of Business Research, vol. 12, no. 2: 94-103.

Hiebl, M. R. W \& Mayrleitner, B. (2019) "Professionalization of management accounting in family firms: the impact of family members", Review of Managerial Science, vol. 13, no. 5: 1037-1068.

Hitt, M.A., Hoskisson, R.E. \& Kim, H. (1997) "International diversification: Effects on innovation and firm performance in product-diversified firms", Academy of Management Journal, vol. 40, no. 4: 767-798.

Ibrahim, A. B., \& McGuire, J. B. (2011) "Family business research: an assessment and future directions", International Journal of Entrepreneurship and Small Business, vol. 12, no. 1: 1-14.

Holland, C. \& Light, B. (1999) "A critical success factors model for ERP implementation”, IEEE Software, vol. 16, no. 3: 30-36.

Kandel, B. K. \& Hota, J. (2012) "Information Technology Adoption in Small Family Businesses for Developing Economies", IUP Journal of Entrepreneurship Development, vol. 9, no. 1: 7-37.

Kanellou, A. \& Spathis, C. (2013) "Accounting benefits and satisfaction in an ERP environment", International Journal of Accounting Information Systems, vol. 14, no. 3: 209-234.

Loudin, K. \& C. Traver (2012) Management Information Systems (12th Edition), Prentice-Hall,

Laudon, K. \& Laudon, J. (2014) Essentials of MIS (11th ed.), Boston, MA: Pearson.

Lutz, E., Schraml, S. \& Achleitner, A. K. (2010) "Loss of control vs risk reduction: Decision factors for hiring non-family CFOs in family firms", CEFS Working Paper Series.

Marinagi, C., Trivellas, P. \& Sakas, D. P. (2014) "The Impact of Information Technology on the Development of Supply Chain Competitive Advantage", Procedia - Social and Behavioral Sciences, vol. 147: 586-591.

Murphy, B. \& Quinn, M. (2018) "The emergence of mandatory continuing professional education at the Institute of Certified Public Accountants in Ireland", Accounting History, vol. 23, no. 1-2: 93-116.

Neubauer, H., Mayr, S., Feldbauer-Durstmuller, B. \& Duller, C. (2012) "Management accounting systems and institutionalization in medium-sized and large family businesses - empirical evidence from Germany and Austria", European Journal of Management, vol. 12, no. 2: 14-69.

O'Regan, P. \& Killian, S. (2014) "Professionals who understand': Expertise, public interest and societal risk governance", Accounting, Organizations and Society, vol. 39: 615-631. 
Ogbonna, E. \& Harris, L. C. (2005) "The adoption and use of information technology: A longitudinal study of a mature family firm”, New Technology, Work \& Employment, vol. 20, no. 1: 2-18.

Parada, M. J., Nordqvist, M. \& Gimeno, A. (2010) "Institutionalizing the family business: The role of professional associations in fostering a change of values", Family Business Review, vol. 23, no. 4: 355-372.

Parker, C. M., Burgess, S. \& Al-Qirim, N. (2015) "A review of studies on information systems and SMEs in high ranked IS journals (2000-2014)", Australasian Journal of Information Systems, vol. 19: 153-173.

Parr, A. \& Shanks, G. (2000) "A model for ERP project implementation", Journal of Information Technology, vol. 15, no. 4: 289-303.

Porter, M. E. \& Millar, V. E. (1985) "How Information Gives You Competitive Advantage", Harvard Business Review, July

Prencipe, A., Bar-Yosef, S. \& Dekker, H. C. (2014) "Accounting research in family firms: Theoretical and empirical challenges", European Accounting Review, vol. 23, no. 3: 361-385.

Quinn, M. (2017) "Are routines "really" an organisational concept? Maybe not for management accounting!", Revista de Ciências Empresariais e Jurídicas, vol. 28: 29-46.

Quinn, M. \& Hiebl, M. R. W. (2018) "Management accounting routines: A framework on their foundations", Qualitative Research in Accounting and Management, vol. 15, no. 4: 535-562.

Quinn, M., Elafi, O. \& Mulgrew, M. (2017) "Reasons for not changing to activitybased costing: A survey of Irish firms", PSU Research Review, vol. 1, no. 1: 63-70.

Rikhardsson, P. \& Kræmmergaard, P. (2006) "Identifying the impacts of enterprise system implementation and use: Examples from Denmark", International Journal of Accounting Information Systems, vol. 7, no. 1: 36-49.

Rikhardsson, P. \& Yigitbasioglu, O. (2018) "Business intelligence \& analytics in management accounting research: Status and future focus", International Journal of Accounting Information Systems, vol. 29: 37-58.

Rikhardsson, P., Karlsson, T., Sigurjonsdottir, T. A. \& Hilmarsson, S. T. (2012) "Rear-view mirror navigation: Pre-crisis management accounting and control practices in Iceland", International Journal of Managerial and Financial Accounting, vol. 4, no. 4: 402-422.

Rom, A. \& Rohde, C. (2007) "Management accounting and integrated information systems: A literature review", International Journal of Accounting Information Systems, vol. 8: 40-68.

Rutherford, M., Kuratko, D.F. \& Holt, D.T. (2008) "Examining the link between "Familiness" and performance: Can the F-PEC untangle the family business theory jungle?", Entrepreneurship: Theory and Practice, vol. 32: 1089-1109.

Salvato, C. \& Moores, K. (2010) "Research on accounting in family firms: Past accomplishments and future challenges", Family Business Review, vol. 23, no. 3: 193-215.

Santhanam, R. \& Hartono, E. (2003) "Issues in linking information technology capability to firm performance", MIS Quarterly, vol. 27, no. 1: 125-153.

Scott, W.R. (2014) Institutions and organizations: ideas, interests and identities, Los Angeles, California:Sage.

Senftlechner, D. \& Hiebl, M. R. (2015) "Management accounting and management control in family businesses: Past accomplishments and future opportunities", Journal of Accounting \& Organizational Change, vol. 11, no. 4: 573-606.

Soleimanof, S., Rutherford, M. W. \& Webb, J. W. (2018) "The intersection of family firms and institutional contexts: A review and agenda for future research", Family Business Review, vol. 31, no. 1: 32-53. 
Songini, L. \& Gnan. L. (2015) "Family involvement and agency cost control mechanisms in family small and medium-sized enterprises", Journal of Small Business Management, vol. 53, no. 3: 748-779.

Songini, L., Gnan, L. \& Malmi, T. (2013) "The role and impact of accounting in family business", Journal of Family Business Strategy, vol. 4, no. 2: 71-83.

Speckbacher, G. \& Wentges, P. (2012) "The impact of family control on the use of performance measures in strategic target setting and incentive compensation: A research note", Management Accounting Research, vol. 23, no. 1: 34-46.

Stewart, A. \& Hitt, M. A. (2012) "Why can't a family business be more Like a nonfamily business?", Family Business Review, vol. 25, no. 1: 58-86.

Strauss, E., Kristandl, G. \& Quinn, M. (2014) "The effects of cloud technology on management accounting and decision making", CIMA Research Executive Summary Series, vol. 10, no. 6.

Sutton, S. (2010) "A research discipline with no boundaries: Reflections on 20 years of defining AIS research", International Journal of Accounting Information Systems, vol. 1, no. 4: 289-296.

Sutton, S. G., Holt, M. \& Arnold, V. (2016) "The reports of my death are greatly exaggerated"-Artificial intelligence research in accounting", 2015 Research Symposium on Information Integrity \& Information Systems Assurance, vol. 22: 60-73.

Thong, J. Y. (1999) "An integrated model of information systems adoption in small businesses", Journal of Management Information Systems, vol. 15, no. 4: 187-214.

Thong, J. Y. \& Yap, C. S. (1995) "CEO characteristics, organizational characteristics and information technology adoption in small businesses", Omega, International Journal of Management Science, vol. 23, no. 4: 429-442.

Umble, E., Haft, R. \& Umble, M. (2003) "Enterprise resource planning: Implementation procedures and critical success factors", European Journal of Operational Research, vol. 146, no. 2: 241-257.

Van der Stede, W. A., Young, S. M., \& Chen, C. X. (2006) "Doing management accounting survey research" in Handbook of Management Accounting Research, Chapman, C., Hopwood, A., Shields, M. (Eds), London: Elsevier, vol. 1: 445-478.

Vasarhelyi, M. A., Alles, M., Kuenkaikaew, S. \& Littley, J. (2012) "The acceptance and adoption of continuous auditing by internal auditors: A microanalysis", International Journal of Accounting Information Systems, vol. 13, no. 3: 267-281.

Volkoff, O., Strong, D.M. \& Elmes, M.B. (2007) "Technological embeddedness and organizational change", Organization Science, vol. 18, no. 5: 832-848.

Wang, L. \& Alam, P. (2007) "Information technology capability: firm valuation, earnings uncertainty, and forecast accuracy", Journal of Information Systems, vol. 21 , no. 2: 27-48.

Yigitbasioglu, O. (2016) "Firms' Information System Characteristics and Management Accounting Adaptability", International Journal of Accounting and Information Management, vol. 24, no. 1: 20-37. 